\title{
Studies of ionic liquids in lithium-ion battery test systems
}

\author{
J. Salminen ${ }^{\mathrm{a}, \mathrm{b}}$, J. M. Prausnitz ${ }^{\mathrm{a}, \mathrm{c}}$, and J. Newman ${ }^{\mathrm{a}}$ \\ ${ }^{a}$ Department of Chemical Engineering, University of California, Berkeley, CA 94720 , \\ USA \\ ${ }^{\mathrm{b}}$ Environmental Energy Technology Division, LBNL, Berkeley, CA 94720, USA \\ ${ }^{c}$ Chemical Sciences Division, LBNL, Berkeley, CA 94720, USA.
}

In this work, thermal and electrochemical properties of neat and mixed ionic liquid lithium salt systems have been studied. The presence of a lithium salt causes both thermal and phase-behavior changes. Differential scanning calorimeter DSC and thermal gravimetric analysis TGA were used for thermal analysis for several imidazolium bis(trifluoromethylsulfonyl)imide, trifluoromethansulfonate, $\mathrm{BF}_{4}$, and $\mathrm{PF}_{6}$ systems. Conductivities and diffusion coefficient have been measured for some selected systems. Chemical reactions in electrode - ionic liquid electrolyte interfaces were studied by interfacial impedance measurements. Lithium-lithium and lithium-carbon cells were studied at open circuit and a charged system. The ionic liquids studied include various imidazolium systems that are already known to be electrochemically unstable in the presence of lithium metal. In this work the development of interfacial resistance is shown in a $\mathrm{Li}\left|\mathrm{BMIMBF}_{4}+\mathrm{LiBF}_{4}\right| \mathrm{Li}$ cell as well as results from some cycling experiments. As the ionic liquid reacts with the lithium electrode the interfacial resistance increases. The results show the magnitude of reactivity due to reduction of the ionic liquid electrolyte that eventually has a detrimental effect on battery performance.

\section{Introduction}

Ionic-liquid electrolytes are promising new materials in power sources for electric vehicles, hybrid cars, electronic and power-storage devices, especially at extreme conditions. Recently, there has been increased interest in research toward using ionic liquids in chemical- process and electrochemical applications. ${ }^{1-12}$ These reviews tend to be concerned primarily with using ionic liquids for separation operations or as media for synthesis of organic and bio-organic products. However, other possible applications of ionic liquids include sensors, solar cells, light-emitting electrochemical cells and electrochromic devices, including displays. ${ }^{13-18}$

Because ionic liquids are non-volatile, and because they are conductive, and nonflammable, they provide potential environmental advantages relative to conventional solvents. Properties and applicability of ionic liquids for electrochemical systems are not easily predicted by means of one or two conductivity measurements. Ionic liquids show a large liquid range that allows a large temperature range for electrochemical devices.

For rechargeable lithium-ion batteries, it is required that any electrolyte provide adequate durability, high conductivity, good transport properties and, very important, chemical and electrochemical stability with safety. ${ }^{19-21}$ Properties of ionic liquids can be modified by molecular design. Numerous ionic liquids are known but only a small number has been 
investigated and for most of them, only a few properties have been studied. Solutes, impurities, undesired or desired reaction products, alter the physical, chemical, and electrochemical behavior of a particular system. Interactions of ionic liquids with materials or unwanted chemical and electrochemical reactions can eliminate the anticipated advantages in industrial applications. They are good solvents but may dissolve solid electrode materials too. Knowledge of pure-component properties of ionic liquids is essential but insufficient to determine their applicability for practical experimentated use in electrochemical devices.

\section{Experimental}

\section{$\underline{\text { Thermal analysis }}$}

Melting points and glass transition temperatures were measured by a differential scanning calorimeter; Perkin Elmer DSC 7. Ionic liquids were dried in a drying pistol at $1 \mathrm{mbar}$ and $60^{\circ} \mathrm{C}$ or in an antechamber for 3 days, both in the presence of drying agent $\mathrm{P}_{2} \mathrm{O}_{5}$. The ionic liquids were stored and sampled in a dry-helium glove box prior to DSC measurements. The DSC apparatus was permanently covered with a dry-nitrogen hood. Samples were cooled to $-120^{\circ} \mathrm{C}$ for 30 minutes, then heated to $80^{\circ} \mathrm{C}$ and cooled again at a rate of $10^{\circ} \mathrm{C} / \mathrm{min}$. Melting-point and glass-transition temperature were taken from the second heating curve where a $5{ }^{\circ} \mathrm{C} /$ min scanning rate was used.

Thermo-gravimetric analysis was carried out with a Perkin Elmer TGA 7 apparatus. The dried ionic liquid samples were again stored and sampled in a dry helium glove box. Then samples were transported in sealed pipettes into the apparatus. The TGA sample holder was under dry-nitrogen flow. Similar size samples, around $23 \mathrm{mg}$, and with the same heating rate of $10{ }^{\circ} \mathrm{C} / \mathrm{min}$ were used for all tested ionic liquids. The obtained TGA curves exhibite zero or only minor weight loss $<1 \%$ below $200^{\circ} \mathrm{C}$. The results show that thermal stability is determined mostly by the nature of the anion. Table 1 shows the observed glass-transition temperatures $T_{\mathrm{g}}$, melting points $T_{\mathrm{m}}$, and decomposition offset temperatures $T_{\mathrm{d}}$ for imidazolium-based ionic liquids.

TABLE I. Glass-transition temperatures, melting points, and offset decomposition temperatures for some imidazolium-based ionic liquids and their lithium salt mixtures measured in this work. $\mathrm{E}=\mathrm{ethyl}-\mathrm{B}=\mathrm{butyl}-, \mathrm{P}=$ propyl-, $\mathrm{H}=$ hexyl-, $\mathrm{O}=$ octyl-, TFSI = bis(trifluoromethylsulfonyl)imide, $\mathrm{Tf}=$ trifluoromethansulfonate. n.d. $=$ not detected.

\begin{tabular}{lccl}
\hline Compound & \multicolumn{1}{c}{$\boldsymbol{T}_{\mathbf{g}} /{ }^{\mathbf{0}} \mathbf{C}$} & $\boldsymbol{T}_{\mathbf{m}} /{ }^{\mathbf{0}} \mathbf{C}$ & $\boldsymbol{T}_{\mathbf{d}} /{ }^{\mathbf{0}} \mathbf{C}$ \\
\hline EMIMTFSI & $-87^{\mathrm{a}}$ & $-18^{\mathrm{a}}$ & 329 \\
BMIMTFSI & $-91^{\mathrm{d}},-87^{\mathrm{b}}$ & $-4^{\mathrm{d}},-3^{\mathrm{b}}$ & $330^{\mathrm{d}}, 330^{\mathrm{c}}$ \\
PMIMTFSI & -90 & & 329 \\
HMIMTFSI & $-81^{\mathrm{a}}$ & $-6^{\mathrm{a}}$ & 331 \\
OMIMTFSI & $-87^{\mathrm{d}},-80^{\mathrm{a}}$ & & $325^{\mathrm{d}}$ \\
BMIMTf $_{\text {BMIMBF }_{4}}$ & $\mathrm{n} \cdot \mathrm{d},-86^{\mathrm{c}}$ & $15^{\mathrm{d}}, 17^{\mathrm{b}}, 13^{\mathrm{c}}$ & $225^{\mathrm{d}}, 230^{\mathrm{c}}$ \\
BMIMPF $_{6}$ & $-86,-83^{\mathrm{b}}$ & & 325 \\
\hline
\end{tabular}

${ }^{\mathrm{a}}$ Ref. [22], ${ }^{\mathrm{b}}$ Ref. [23], ${ }^{\mathrm{c}}$ Ref. [24], ${ }^{\mathrm{d}}$ Ref. [25].

BMIMTf, Fluka, purity $>97$ wt-\%, BMIMBF $_{4}$, Fluka, purity $>98$ wt- $\%$, BMIMPF $_{6}$, Fluka, purity $>96$ wt-\%. All chemicals obtained from Fluka were used as received.

BMIMTFSI, OMIMTFSI synthesis and procedure in detail in. ${ }^{25}$

EMIMTFSI, PMIMTFSI, HMIMTFSI all electrochemically purified. Obtained from Hydro Quebec, Canada.

Addition of a lithium salt into an ionic liquid changes both thermal stability and phase behavior. Addition of a lithium salt depresses the melting point peak and shows an 
increase in $T_{\mathrm{g}}$ temperature. Neat $\mathrm{BMIMBF}_{4}$ has no melting point nor does its solution with $\mathrm{LiBF}_{4}$. Addition of lithium triflate salt into BMIMTf lowers the melting point peak significantly, observed from the DSC curve. Also, the glass-transition temperature for the $1 \mathrm{~mol} / \mathrm{kg}$ LiTf system is slightly higher than that for the neat liquid $\left(-80^{\circ} \mathrm{C}\right.$ as opposed to $\left.86^{\circ} \mathrm{C}^{24}\right)$. Figure 1 shows the effect of added lithium salt on the glass transition point for $\mathrm{BMIMBF}_{4}-\mathrm{LiBF}_{4}$ and BMIMTf - LiTf systems.

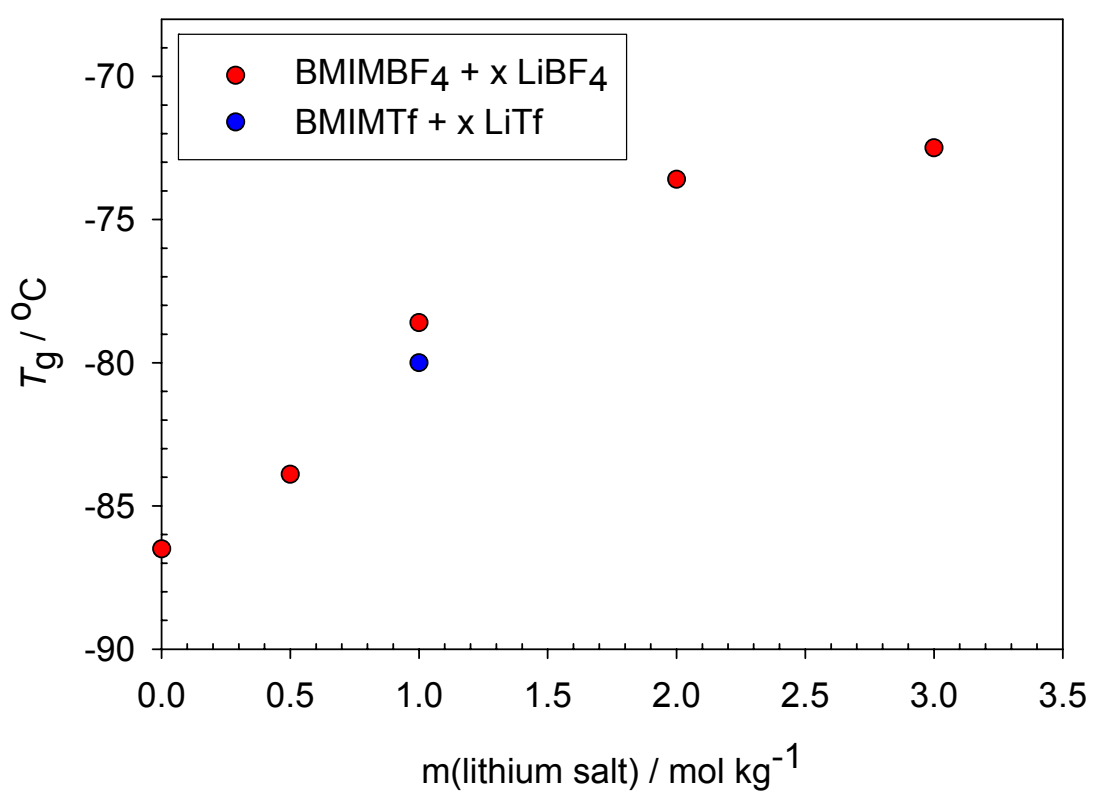

Figure 1. Glass transition temperature $T_{\mathrm{g}}$ increases as a function of added lithium salt.

\section{$\underline{\text { Transport properties }}$}

Conductivities of $\mathrm{BMIMBF}_{4}-\mathrm{LiBF}_{4}$ mixtures and neat BMIMTf and BMIMTFSI were measured. The results are shown in Figure 2. For results above $30^{\circ} \mathrm{C}$ the samples were kept at constant temperature for at least 2 hours prior to measurement. Low temperature samples $5,-5,-20^{\circ} \mathrm{C}$ were kept at least for 15 hours at constant temperature prior to measurement. The results were obtained by the AC impedance method. The measurements were carried out in a (steel | ionic liquid + lithium salt | steel), Swageloktype cell. Solatron, Schlumberger 1254 four-channel frequency response analyzer was used. The frequency sweep was from 65535 to $0.1 \mathrm{~Hz}$ at $5 \mathrm{mV}$ AC amplitude. With known cell dimensions and the bulk resistance $\Omega$, the conductivity $\sigma$ is obtained as follows:

$\sigma(\mathrm{S} / \mathrm{cm})=\frac{\text { thickness }\left(\mathrm{cm}^{2}\right)}{\text { surface } \operatorname{area}\left(\mathrm{cm}^{2}\right)} \cdot \frac{1}{\Omega(\mathrm{ohm})}$

The measurements showed that the addition of lithium salt decreased the conductivity in $\mathrm{BMIMBF}_{4}, \mathrm{BMIMTf}$ and BMIMTFSI systems. It is important to keep both the ionic liquid and the lithium salt dry and in the glove box to avoid any moisture. Impurities like 
absorbed water and organic additives increase the conductivity and lower the viscosity of the system.

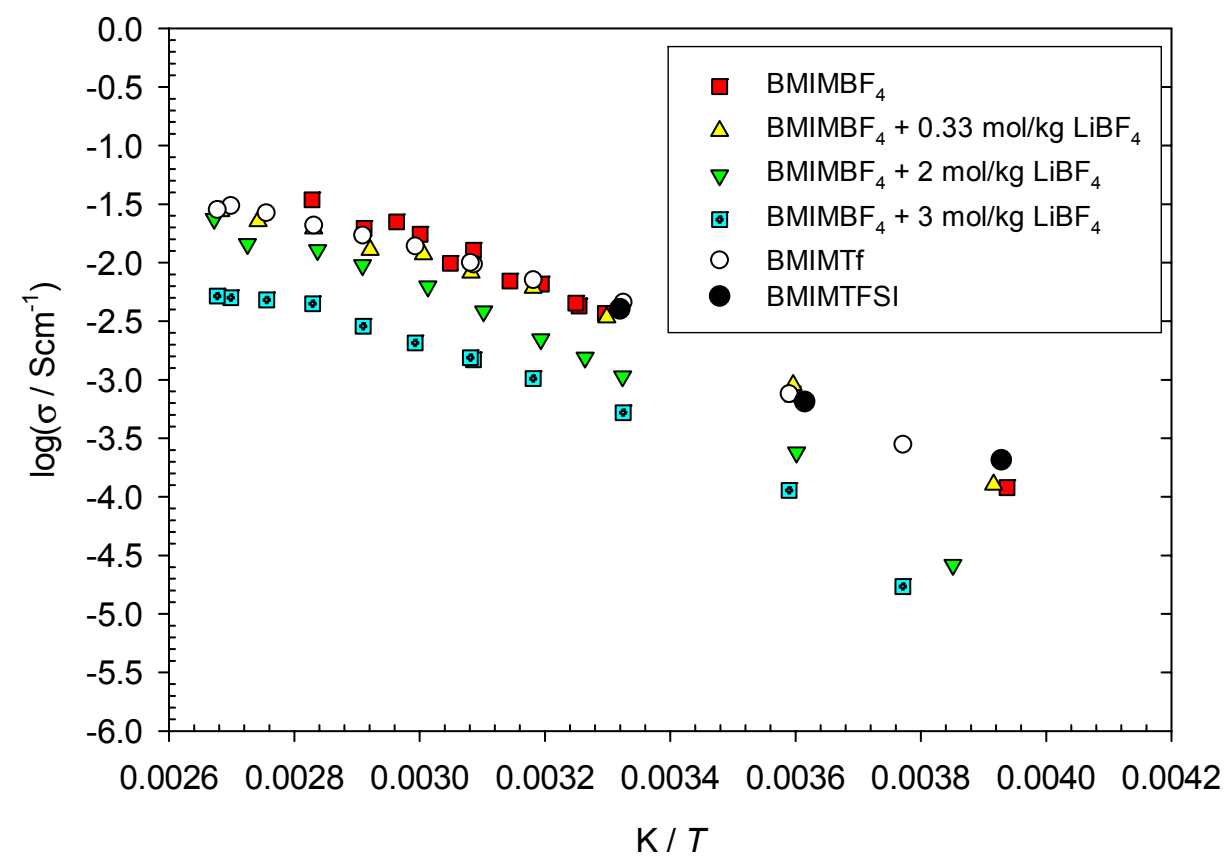

Figure 2. Conductivities of $\mathrm{BMIMBF}_{4}+\mathrm{LiBF}_{4}$ systems as a function of temperature. Neat BMIMTf, BMIMBF 4 and BMIMTFSI conductivities are shown for comparison.

The Diffusion coefficient of the $\mathrm{Li}^{+}$ion was measured in symmetrical $(\mathrm{Li} \mid \mathrm{BMIMBF} 4+1$ $\mathrm{mol} / \mathrm{kg} \mathrm{LiBF} 4 \mathrm{Li}$ ) cell. The measurement was carried out by a relaxation method at $30^{\circ} \mathrm{C}$. A $50 \mu \mathrm{A} \mathrm{cm}{ }^{2}$ current density was applied for 50 minutes and was then allowed to relax at open circuit for 15 minutes. The diffusion coefficient was determined from the derivative of the open circuit potential with a respect to time at constant temperature using Equation 2. Figure 3 shows the natural logarithm of the open circuit potential as a function of time.

$D_{s}=-\frac{L^{2}}{\pi^{2}} \frac{d(\ln \Delta \Phi)}{d t}$

Diffusion coefficient $1.0 \cdot 10^{-8} \mathrm{~cm}^{2} \mathrm{~s}^{-1}$ was obtained for $\mathrm{Li}^{+}$. This value is between that for polymer electrolytes and that for common organic solvents used with lithium salts. ${ }^{26}$ 


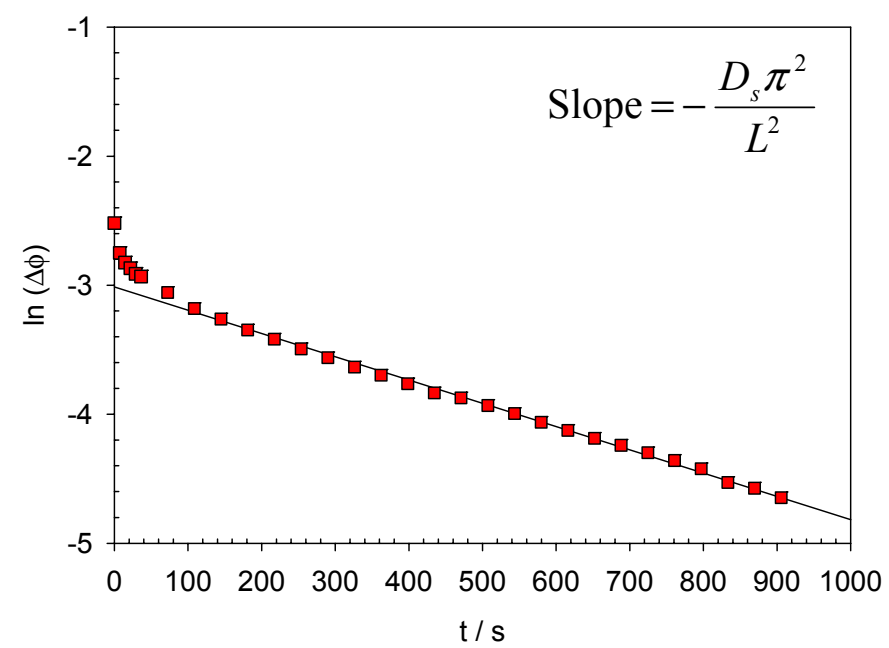

Figure 3. Natural logarithm of the open circuit potential as a function of time for ( $\mathrm{Li}$ | $\mathrm{BMIMBF}_{4}+1 \mathrm{~mol} / \mathrm{kg} \mathrm{LiBF} 4 \mid \mathrm{Li}$ ) cell after charging $3000 \mathrm{~s}$ at $50 \mu \mathrm{A} \mathrm{cm}{ }^{-2}$.

\section{Interfacial resistance in a lithium-lithium cell}

For electrochemical applications using lithium batteries, we must be sure that the ionic liquid is stable over a wide range of electric potential. When lithium salt is added, it be stable in a wide temperature range. For lithium batteries in hybrid vehicles, stability of the electrolyte with respect to the electrodes at high current densities is necessary to give sufficient energy for peak-power needs. In this case, the non-volatility and nonflammability of an ionic liquid provide an advantage. Organic components, including ionic liquids, are not electrochemically stable against lithium metal but exhibit different tolerances against it. Electrochemical stability can be studied by measuring the growth of interfacial impedance between electrode and electrolyte. Toward that end, we measure the temperature-dependent and time-dependent interfacial impedance using a frequencyresponse analyzer. The interfacial-resistance studies pertain to a symmetrical $(\mathrm{Li} \mid$ $\mathrm{BMIMBF}_{4}+\mathrm{LiBF}_{4} \mid \mathrm{Li}$ ) cell. A Swagelok cell is used with a frequency sweep from $65535 \mathrm{~Hz}$ to $0.1 \mathrm{~Hz}$ at $5 \mathrm{mV} \mathrm{AC}$ amplitude.

Reactivities of ionic liquid-lithium salt electrolytes were studied in $\mathrm{Li}$ - $\mathrm{Li}$ and $\mathrm{Li}$-carbon cells. Figure 4 shows the increase of the interfacial impedance $Z^{\prime}$ in the presence of lithium metal in a ( $\left.\mathrm{Li}\left|\mathrm{BMIMBF}_{4}+2 \mathrm{~mol} / \mathrm{kg} \mathrm{LiBF} 4\right| \mathrm{Li}\right)$ cell at open circuit at $30^{\circ} \mathrm{C}$. Z' is the real part of the interfacial impedance and $Z$ ' is the imaginary part of the impedance. From Z' we obtain the resistance of the system that, in this case, increases with time. 


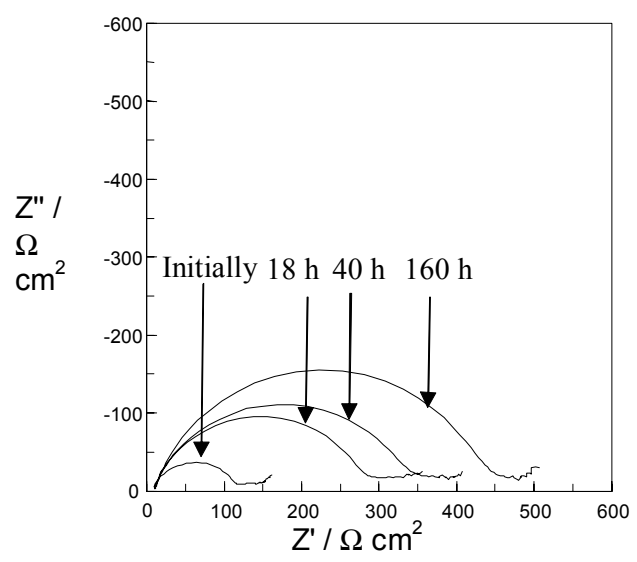

Figure 4. Increase of interfacial impedance as a function of time in a $\left(\mathrm{Li} \mid \mathrm{BMIMBF}_{4}+2\right.$ $\mathrm{mol} / \mathrm{kg} \mathrm{LiBF} 4 \mid \mathrm{Li}$ ) cell at open circuit at $30^{\circ} \mathrm{C}$.

As shown in Figure 5, initial interfacial resistance for a $2 \mathrm{~mol} / \mathrm{kg}$ solution is smaller than that for a $1 \mathrm{~mol} / \mathrm{kg} \mathrm{LiBF}_{4}$ solution.

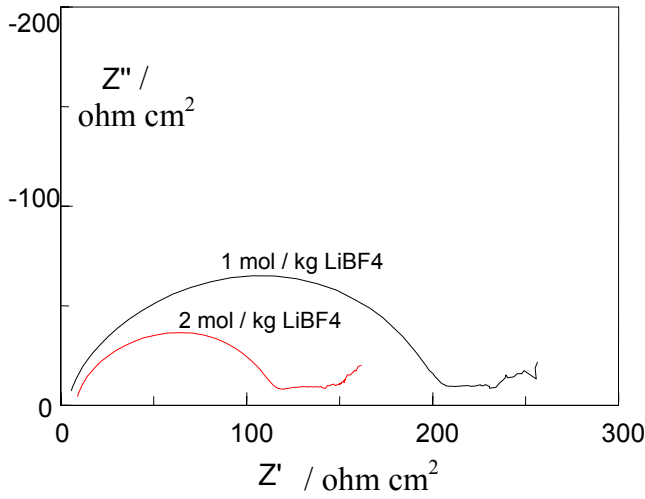

Figure 5. Initial interfacial impedance in ( $\mathrm{Li} \mid \mathrm{BMIMBF}_{4}+1$ or $\left.2 \mathrm{~mol} / \mathrm{kg} \mathrm{LiBF} 4 \mid \mathrm{Li}\right)$ cells at open circuit at $30^{\circ} \mathrm{C}$.

\section{Cycling tests}

Cell cycling has been carried out for Li-Li cells and for Li-carbon anode cells. Figure 6 shows cycling results for the ( $\left.\mathrm{Li}\left|\mathrm{BMIMBF}_{4}+1 \mathrm{~mol} / \mathrm{kg} \mathrm{LiBF} \mathrm{L}_{4}\right| \mathrm{Li}\right)$ cell. After five cycles passing $\pm 0.1 \mathrm{mAcm}^{2}$ current and 15 min open circuit potential, the growth of dendrites is evident. Also, the interfacial impedance rises to a few thousand $\Omega \mathrm{cm}^{2}$. Figure 7 shows the effect of 10 cycles passing $\pm 0.1 \mathrm{~mA} \mathrm{~cm}{ }^{2}$ current. The recovered electrodes show mossy lithium in the middle circle of Figure 8. 

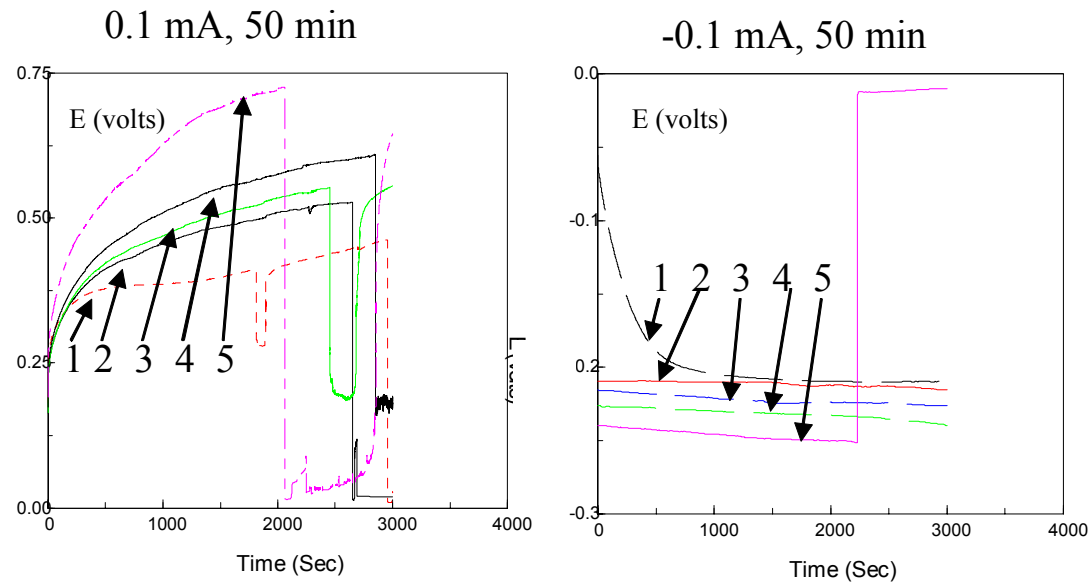

Figure 6. First five charging curves for the ( $\left.\mathrm{Li}\left|\mathrm{BMIMBF}_{4}+1 \mathrm{~mol} / \mathrm{kg} \mathrm{LiBF} 4\right| \mathrm{Li}\right)$ cell. The curves indicate surface roughening and the formation of dendrites, a common feature with all currently used electrolytes. ${ }^{27}$
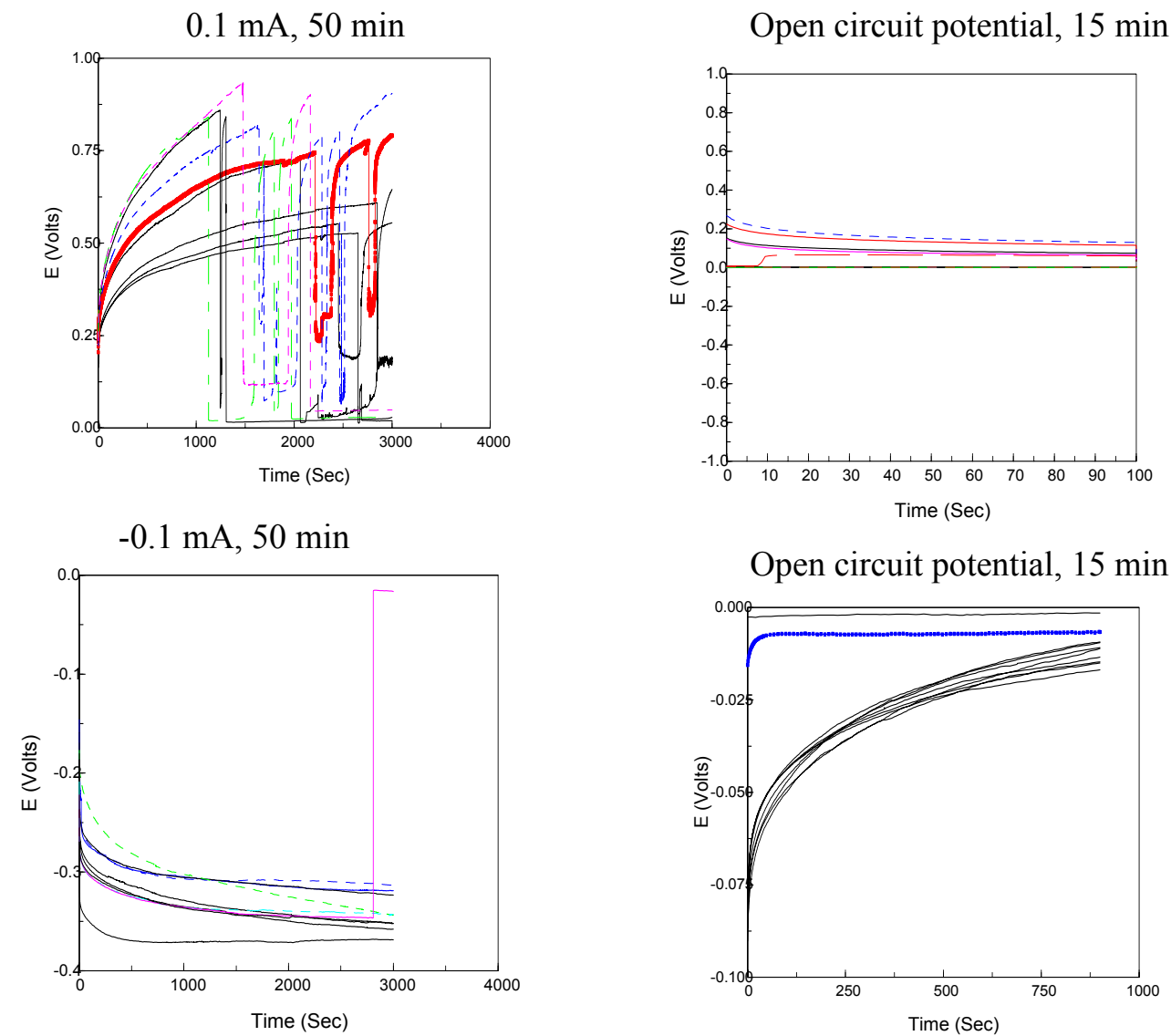

Figure 7. Ten charging and relaxation curves for the $\left(\mathrm{Li} \mid \mathrm{BMIMBF}_{4}+1 \mathrm{~mol} / \mathrm{kg} \mathrm{LiBF} 4\right.$ Li) cell. 


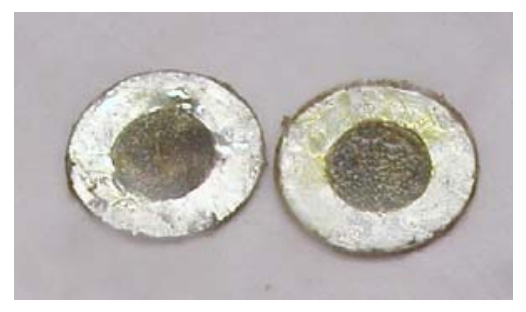

Figure 8. The presence of lithium coins after 10 cycles passing $\pm 0.1 \mathrm{~mA} \mathrm{~cm}{ }^{2}$ current in a $\left(\mathrm{Li} \mid \mathrm{BMIMBF}_{4}+1 \mathrm{~mol} / \mathrm{kg} \mathrm{LiBF} 4 \mathrm{Li}\right)$ cell. Shiny lithium metal on the outer layer and mossy lithium in the middle are clearly observed.

A few cycling tests were performed with a $\left(\mathrm{Li}\left|\mathrm{BMIMBF}_{4}+1 \mathrm{~mol} / \mathrm{kg} \mathrm{LIBF}_{4}\right| \mathrm{C}\right)$ cell. The initial impedance was $65 \Omega \mathrm{cm}^{2}$ and the open-circuit potential was $3.1 \mathrm{~V} . \pm 50 \mu \mathrm{A}$ $\mathrm{cm}^{2}$ current was passed for $500 \mathrm{~s}$, and $90 \mathrm{~s}$ open circuit. The cell voltage changed between 3.5 to $1.8 \mathrm{~V}$ as shown in Figure 9. Figure 10 show the development of interfacial impedance during cycling. Initial impedance at the beginning, near $65 \Omega \mathrm{cm}^{2}$, increased to $400 \Omega \mathrm{cm}^{2}$ after 6 cycles.

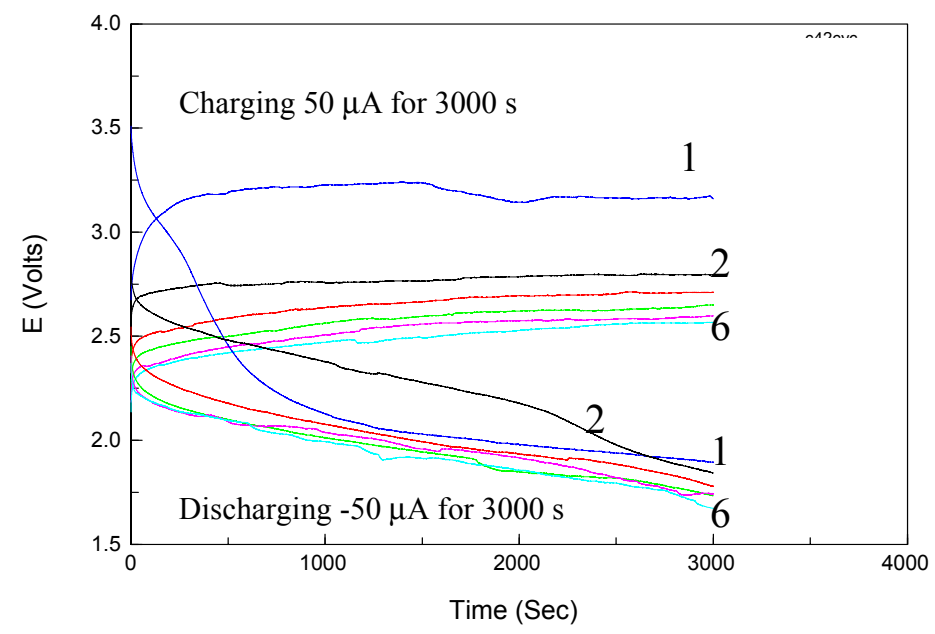

Figure 9. The cell voltage changed between 3.5 to $1.8 \mathrm{~V}$ in $\left(\mathrm{Li} \mid \mathrm{BMIMBF}_{4}+1 \mathrm{~mol} / \mathrm{kg}\right.$ $\left.\mathrm{LIBF}_{4} \mid \mathrm{C}\right)$ cell. Cycling tests were made passing a current of $\pm 50 \mu \mathrm{A} \mathrm{cm}{ }^{2}$. After charging and discharging, the system was at open-circuit potential for $90 \mathrm{~s}$. 


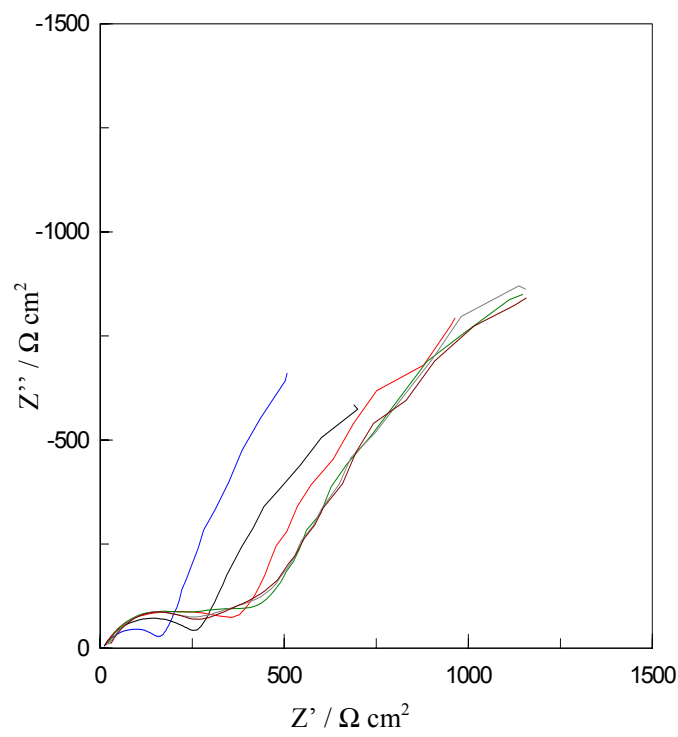

Figure 10. Interfacial impedance after different charging cycles. Initial impedance at the beginning, near $65 \Omega \mathrm{cm}^{2}$, increases to $400 \Omega \mathrm{cm}^{2}$ after 6 cycles.

After 12 hours at open circuit the impedance rose to $500 \Omega \mathrm{cm}^{2}$. Further cycling was carried out by charging $500 \mathrm{~s}$ at $\pm 100 \mu \mathrm{A}$, followed by $90 \mathrm{~s}$ at open circuit potential. In Figure 11, discharge is shown as the downward peak after a large potential drop. This indicates zero discharge capacity and large over-potential on charging. After ten cycles the interfacial impedance increased to $4000 \Omega \mathrm{cm}^{2}$, showing the presence of a large insulating layer between electrodes and electrolyte.

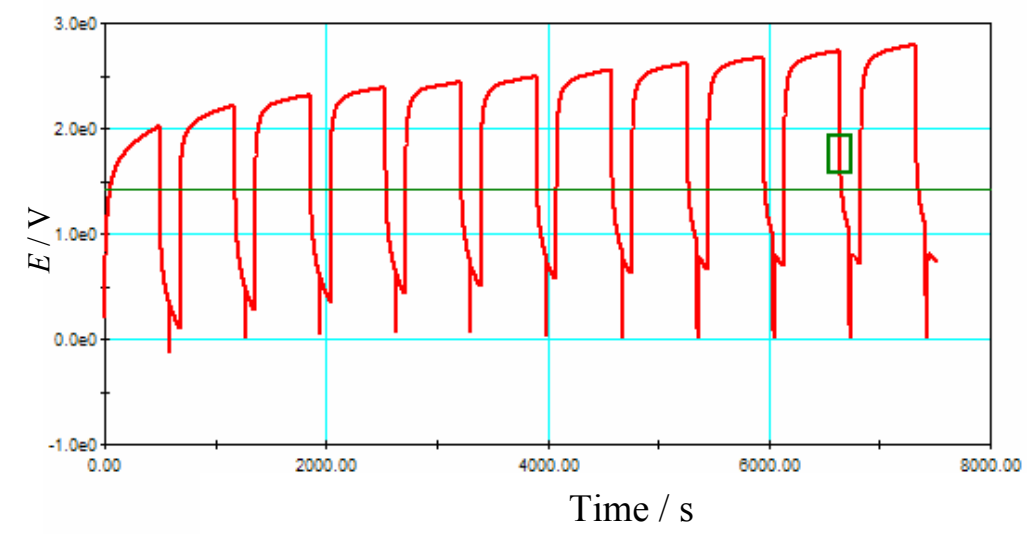

Figure 11. Voltage-time curve shown for $\left(\mathrm{Li}\left|\mathrm{BMIMBF}_{4}+1 \mathrm{~mol} / \mathrm{kg} \mathrm{LIBF}_{4}\right| \mathrm{C}\right)$ cell. when charging $500 \mathrm{~s}$ at $\pm 100 \mu \mathrm{A}$. After charging and discharging, the cell was at opencircuit potential for $90 \mathrm{~s}$. Discharge is shown as the peak downwards after a large potential drop. This indicates zero discharge capacity and large over-potential on charging. 


\section{Discussion and Conclusions}

Ionic liquids studied in this work show relatively good thermal stability. The addition of lithium salts alters thermal stabilities. Lithium triflate showed a small increase in decomposition temperature while the addition of lithium tetrafluorborate decreased thermal stability. Absorbed water changes both TGA and DSC results and great care was taken to avoid any moisture in the samples. Because ionic liquids absorb moisture from air, it is necessary to dry them and to store them in a glove box. Drying the samples in a drying pistol at $60^{\circ} \mathrm{C}$ in the presence of $\mathrm{P}_{2} \mathrm{O}_{5}$ was found adequate. Also, the lithium salt dissolved in the ionic liquid must be kept in a dry glove box. From DSC data, the melting-point endothermic peak declines when lithium salt is dissolved in an ionic liquid. Ionic liquids form glasses at low temperatures that can be observed at the glass-transition point $T_{\mathrm{g}}$. That increases as a function of added lithium salt and qualitatively we expect the viscosity to increase and conductivity to decrease.

Measured conductivities were of the order of $\mathrm{mScm}^{-1}$ at $25^{\circ} \mathrm{C}$, sufficient for battery applications. The measured diffusion coefficient for $\mathrm{Li}^{+}$was found lower than that in typical organic solvent-lithium salt systems but higher than that found in polymer-lithium salt systems. Together, the diffusion coefficient and conductivity properties must be large for good battery performance.

More importantly, from a working battery point of view, it is essential that an ionic liquid - lithium salt system be chemically and electrochemically stable in the presence of lithium metal, lithium ions, and other electrode materials. This has to be valid both at open-circuit potential as well as at charging and discharging processes. A stable ionic liquid decreases the (undesirable) tendency to form side reactions that contribute to power- and capacity-fade of a battery. We have studied chemical and structural changes in the electrodes including the possible (undesirable) formation of dendrites that lead to battery short-out. The ionic-liquid / lithium-salt system $\left(\mathrm{BMIMBF}_{4}+\mathrm{LiBF}_{4}\right)$ showed large interfacial impedance at open- circuit potential. This system showed relatively good transport properties but poor electrochemical and chemical stability. The increase of interfacial impedance is a result of the reactivity of the electrolyte with the electrode. The observed reactivity of ionic liquids with the electrodes brings additional obstacles for their use in lithium-ion batteries. However, applications at elevated temperatures may be attractive due to increased safety.

It appears that ionic liquids containing an imidazolium cation are not useful for lithium batteries. We are therefore now investigating the properties of ionic liquids containing other cations.

\section{Acknowledgment}

For financial support, the authors are grateful to the office for Basic Sciences of the US Dept. of Energy and Technology Agency of Finland (TEKES). 


\section{References}

1. M. H. Abraham, Chem. Soc. Rev., 22, 2, 73 (1993).

2. M. H. Abraham, A. M. Zissimos, J. G. Huddleston, H. D. Willauer, R. D. Rogers and W. E. Acree, Ind. Eng. Chem. Res., 42, 3, 413 (2003).

3. J. L. Anthony, E. J. Maginn and J. F. Brennecke., J. Phys. Chem. B, 106, 29, 7315 (2002).

4. J. F. Brennecke and E. J. Maginn, AIChE J., 47, 11, 2384 (2001).

5. J. Dupont, R. F. de Souza and P. A. Z. Suarez, Chem. Rev., 102, 10, 3667 (2002).

6. K. N. Marsh, J. A. Boxall and R. Lichtenthaler, Fluid Phase Equil., 219, 1, 93 (2004).

7. C. F. Poole, J. Chromat., 1037, 49 (2004).

8. R. D. Rogers and K. R. Seddon, ACS Symposium Series, 818, (2002).

9. T. Welton, Chem. Rev., 99, 8, 2071 (1999).

10. A. P. Abbott, G. Capper, D. L. Davies, R. K. Rasheed, P. Shikotra, Inorg. Chem., 44, 19, 6497 (2005).

11. M. Dietz, J. A. Dzielawa, M. P. Jensen, J. V. Beitz, M. Borkowski, ACS Symposium Series 902, Ionic Liquids IIIB: Fundamentals, Progress, Challenges, and Opportunities, 2 (2005).

12. K. Nakashima, F. Kubota, T. Maruyama, and M. Goto, Ind. Eng. Chem. Res., 44, 12, 4368 (2005).

13. Y. G. Lee and T.-C. Chou, Biosensors and Bioelectronics, 20, 33 (2004).

14. P. W. Wang, S. M. Zakeerudding, J.-E. Moser and M. Grätzel, J. Phys. Chem. B, 107, 13280 (2003).

15. W. Lu et al., Science, 297, 9, 983 (2002).

16. H. Paulsson, A. Hagfeldt, L. Kloo, J. Phys. Chem. B, 107, 13665 (2003).

17. C. Yang, Q. Sun, J. Qiao and Y. Li, J. Phys. Chem. B, 107, 12981 (2003).

18. W. Lu, A. G. Fadeev, B. Qi and B. R. Mattes, J. Electrochem. Soc., 151, 2, H33 (2004).

19. P. C. Howlett, D. C. MacFarlane and A. F. Hollenkamp, Electrochem. Solid-State Lett., 7, 5, A97 (2004). 
20. J. H. Shin, W. A. Henderson, and S. Passerini, Electrochem. Commun., 5, 1016 (2003).

21. B. Garcia et al., Electrochim. Acta, 49, 26, 4583 (2004).

22. H. Tokuda et al., J. Phys. Chem. B, 109, 6103 (2005).

23. H. Tokuda et al., J. Phys. Chem. B, 108, 16593 (2004).

24. C. P. Fredlake, J. M. Crosthwaite, D. G Hert, S. N. Aki, J. F. Brennecke, J. Chem. Eng. Data, 49, 954 (2004).

25. N. Papaiconomou, N. Yakelis, J. Salminen, R. Bergman and J. M. Prausnitz, J. Chem. Eng. Data (in press).

26. K. E. Thomas, S. Sloop, J. Kerr, J. Newman, J. Power Sources, 89, 132 (2000).

27. J. Newman and C. Monroe, J. Electrochem. Soc., 151, A880 (2004). 